\title{
A new Luciolinae firefly (Coleoptera: Lampyridae) from the Baltic Amber
}

\section{Новый светлячок подсемейства Luciolinae (Coleoptera: Lampyridae) из балтийского янтаря}

\author{
Sergey V. Kazantsev \\ C.В. Казанцев
}

Insect Centre, Donetskaya 13-326, Moscow 109651, Russia.

Инсект-центр, ул. Донецкая 13-326, Москва 109651, Россия. E-mail: kazantss@mail.ru

\begin{abstract}
KEY WORDS: Coleoptera, Lampyridae, new genus, new species, Baltic Amber, Eocene.
КЛЮЧЕВЫЕ СЛОВА: Coleoptera, Lampyridae, новый род, новый вид, Балтийский янтарь, эоцен.
\end{abstract}

ABSTRACT: A new fossil genus of fireflies, Eoluciola gen.n., and a new species, Eoluciola varang sp.n., are described from the Baltic Amber. The new taxon is placed in Luciolinae, between Luciolini and Pristolycini.

РЕЗЮМЕ: Из Балтийского янтаря описывается новый род Lampyridae, Eoluciola gen.n., и новый вид, Eoluciola varang sp.n. Новый таксон помещается в Luciolinae, между трибами Luciolini и Pristolycini.

First fossil specimens of fireflies were reported from the Baltic Amber more than a hundred years ago [Klebs, 1910]; however, it was not until 2012 that the first amber lampyrid taxon was described [Kazantsev, 2012]. The taxon was discovered in the Baltic Amber and was placed in the subfamily Ototretinae as a new genus, Electotreta Kazantsev, 2012.

A study of further Baltic Amber inclusions, this time from the Hoffeins collection in Hamburg, allows adding another new taxon, related to Luciola Laporte, 1833. Luciola had already been known to have fossil members. A fossil Luciola species from Rott brown coals in Germany (Lower Oligocene) was described in the middle of the XIX century [Heyden, 1862]; apparently another species from the Baltic Amber was referred to by Klebs [1910] as just Luciola sp. The discovered amber fossil, however, cannot be attributed to Luciola, or any other lucioline taxon, and appears to represent a new, apparently now extinct, genus.

The description of the new genus and the new species is presented below.

\section{Eoluciola Kazantsev gen.n.}

Type species: Eoluciola varang Kazantsev sp.n.

DESCRIPTION. Female. Alate, flattened, elongate (Fig. 1). Head small, transverse, not exposed. Eyes relatively small, spherical (Fig. 2). Palps small, slender; ultimate palpomeres elongate and pointed. Antennal sockets separated by ca. their diameter (Fig. 2). Antenna 11-segmented, relatively short, filiform; pedicel (antennomere 2) elongate, about as long as antennomere 3 and subsequent antennomeres; pubescence on antennomeres 3-11 short and suberect (Figs 1-2).

Pronotum transverse, narrowing anteriorly from posterior angles, with slightly explanate sides and acute posterior an- gles; densely punctate (Fig. 1). Prosternum short, V-shaped (Fig. 2). Scutellum triangular, slightly rounded at apex (Fig. 1). Mesoventrite short, V-shaped. Discrimen almost attaining to mesoventrite. Elytra elongate, slightly convex, elliptical, with three elytral costae, first (from suture) attaining to elytral middle, second to elytral apex, third to elytral five sixths, densely punctate, punctures arranged in four longitudinal rows between suture and costae 1-3 and more rows between costa 3 and lateral margin; short, erect pubescence at costae and at margins (Fig. 1). Epipleuron attaining to elytral apex, widest near humerus (Fig. 2). Metathoracic wings fully developed.

Legs relatively short and slender; hind coxae elongate and separated; trochanters small and short; femurs and tibiae straight, narrow, tibiae slightly longer than femurs; tarsomeres 1-3 narrow, without plantar pads, tarsomere 4 deeply incised, with plantar pads (Figs 1-2); claws simple.

Abdomen with seven ventrites, first medially almost entirely incised and overlapped by metacoxae; exposed portion of ultimate ventrite transverse, trapezoidal; ventrites without photic organs (Fig. 2).

Male. Unknown.

ETYMOLOGY. The name of the new genus is a combination of "Eocene", and the genus name "Luciola". Gender feminine.

DIAGNOSIS. Eoluciola gen.n. is distinguishable from Luciola by the densely punctate pronotum and elytra, prominent elytral costae (Fig. 1) and absent light organs on female ventrites (Fig. 2). Eoluciola gen.n. seems to be more similar to Curtos Motschulsky, 1845, also of the tribe Luciolini, but is separable by the presence of three conspicuous elytral costae and absent light organs in the female. It also resembles Pristolycus Gorham, 1883, from the tribe Pristolycini, differing by the short filiform antennae, shorter pronotum with oblique sides and absent median carina (Fig. 1), as well as by the shorter first elytral costa (Fig. 1).

As Eoluciola gen.n. demonstrates characters of both Luciolini (short filiform antennae, short pronotum with oblique sides and absent median carina) and Pristolycini (three prominent elytral costae and absent light organs), it is placed in Luciolinae incertae sedis at the root of the clade.

\section{Eoluciola varang Kazantsev sp.n.} Figs 1-2

MATERIAL: Holotype,, , No.1687-1, Baltic amber, Eocene (Senckenberg Deutsches Entomologisches Institut, Müncheberg, Germany).

DESCRIPTION. Female. Dark brown.

Eyes relatively small, interocular dorsal distance ca. 2.5 


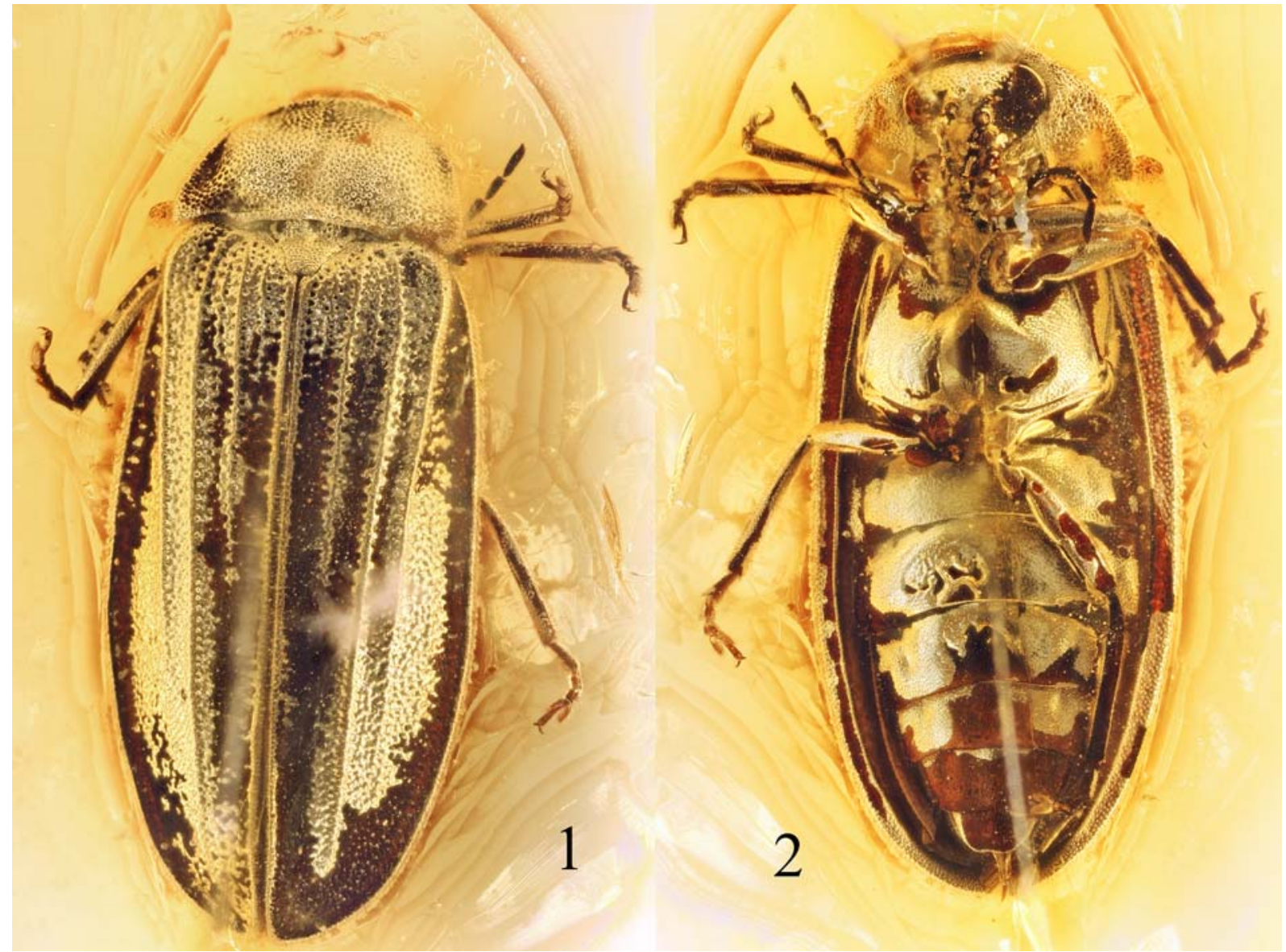

Figs 1-2. General view of Eoluciola varang gen.n., sp.n., holotype female: 1 - dorsally; 2 - ventrally.

Рис. 1-2. Внешний вид Eoluciola varang gen.n., sp.n., голотип, самка: 1 - сверху; 2 - снизу.

times greater than eye radius. Ultimate maxillary palpomere ca. 1.5 times longer than wide. Antennae filiform, attaining to elytral third, antennomere 2 ca. 1.2 times shorter than antennomere 3 (Fig. 2).

Pronotum transverse, ca. 2 times as wide as long, sinuate anteriorly, with prominent acute posterior angles. Scutellum with fine dense punctuation, feebly emarginate at apex (Fig. 1).

Elytra ca. 3 times as long as wide at humeri, slightly elliptical, widest at two thirds (Fig. 1).

Tarsomere 1 as long as tarsomeres 2-3 combined and subequal in length to tarsomere 5 (Fig. 2).

Length (from anterior head margin to end of elytra): 6.6 $\mathrm{mm}$. Width (humerally): $2.4 \mathrm{~mm}$.

Syninclusions. None.

Male. Unknown.

ETYMOLOGY. The name of the new species is derived from the noun «Varang», the Old Russian for «Varangian», also one the former names of the Baltic Sea.

DIAGNOSIS. Eoluciola varang sp.n., the only known representative of the genus, is easily distinguishable from other luciolines by the generic characters.

Whereas Luciola is distributed rather widely in the Eastern Hemisphere [although the concept of the genus is in the process of alteration - e.g., Ballantyne \& Lambkin, 2009; Fu at al., 2010], Curtos and Pristolycus, with which Eoluciola gen.n. appears to have closest affinities, are known from the Eastern Palaearctic, from the Kuril Islands and Japan through China to Northern Vietnam (Pristolycus), and East- ern Palaearctic and Sunda Archipelago (Curtos). The occurrence of an apparent relative of the two taxa in the Baltic Amber testifies to the possible basal position of Curtos in Luciolini and Pristolycus (Pristolycini) in Luciolinae.

ACKNOWLEDGEMENTS. It is my pleasant duty to express sincere gratitude to Ms. Christel Hoffeins and Mr. Hans Werner Hoffeins (Hamburg) for the possibility to study the Baltic Amber beetle specimens. My thanks are also due to Prof. K.V. Makarov (Moscow) for his kind help with the photos of Eoluciola varang gen.n., sp.n.

\section{References}

Ballantyne L.A., Lambkin C.L. 2009. Systematics of Indo-Pacific fireflies with a redefinition of Australasian Atyphella Olliff, Madagascan Photuroluciola Pic, and description of seven new genera from the Luciolinae (Coleoptera: Lampyridae) // Zootaxa. Vol.1997. P.1-188.

Fu X.H., Ballantyne L.A., Lambkin C. 2010. Aquatica gen. nov. from mainland China with a description of Aquatica wuhana sp. nov. (Coleoptera: Lampyridae: Luciolinae) // Zootaxa. Vol.2530. P.1-18.

Heyden C. v. 1862. Gliederthiere aus der Braunkohle des Niederhein's, der Wetterau und der Rohn //Palaeontographica. B.10. S.62-82, 1 pl.

Kazantsev S.V. 2012. New omethid and lampyrid taxa from the Baltic Amber (Insecta: Coleoptera) // Zootaxa. Vol.3186. P.59-63.

Klebs R. 1910. Über Bernstein einschlusse im allgemeinen und die Coleopteren meiner Bernsteinsammlung // Schriften der Physikalisch-ökonomischen gesellshaft zu Königsberg. Bd.51. Hf.3. S.217-242. 